\title{
An environmental scan of wellness initiatives and programs at Canadian academic emergency medicine programs: How far have we come?
}

\author{
Rodrick Lim, MD*†; Brittany Cameron, MD; Sara Gray, MD; Louise Rang, MDף; \\ Kristine Van Aarsen (1), MSc ${ }^{\#}$
}

\section{CLINICIANS CAPSULE}

What is known about the topic?

It is unknown what crucial wellness activities and policies currently exists in Canadian academic emergency medicine programs.

What did this study ask?

What is the current state of wellness activities and policies in Canadian academic emergency medicine programs? What did this study find?

This review found important work across the domains of formal wellness programs, scheduling, wellness measures, career transitions, and financial considerations.

Why does this study matter to clinicians?

Highlighting local strengths and weaknesses, this environmental scan can aid programs in determining areas to focus efforts.

\section{ABSTRACT}

Objectives: We sought to conduct a major objective of the Canadian Association of Emergency Physicians (CAEP) Wellness Committee, an environmental scan of the academic emergency medicine programs across the 17 Canadian medical schools.

Methods: An 89-question questionnaire was distributed to academic heads or wellness leads. The responses were verified by the lead author to ensure that the questions were answered completely and consistently.

Results: While formal wellness programs may exist in varying degrees across the 17 universities, most were found to exist only at local, divisional, or departmental levels. A broad variability of established leadership positions exists. Shift practices varied greatly. In day to day practice, availability for food and debriefing were high and childcare, sleep rooms, and follow-up following critical incidents were low. Sabbaticals existed in the majority of centers. Roughly $50 \%$ of departments have gender equity program and annual retreats. Centers report programs for the initiation of leaves $(82 \%)$, onboarding $(64 \%)$, and reorientation $(94 \%)$. Support of health benefits (76\%) and pensions (76\%) depended on type of appointment and relationship to the university. Fiscal transparency was reported in $53 \%$ of programs.

Conclusion: Wellness and burnout are critical issues for emergency medicine in Canada. This comprehensive review of wellness programs identifies areas of strength, but also allows identification of areas of improvement for future work. Individual centers can identify common options when developing or expanding their wellness programs.

\section{RÉSUMÉ}

Objectif: L'étude visait à atteindre un des grands objectifs du comité de mieux-être de l'ACMU, soit la réalisation d'une analyse environnementale des programmes de médecine d'urgence, dans les 17 écoles de médecine au Canada.

Méthode: Un instrument d'enquête composé de 89 questions a été envoyé aux chefs des services visés dans les universités ou aux responsables du mieux-être. L'auteur principal a par la suite vérifié les réponses afin de s'assurer que les sujets concernés avaient répondu, de la même manière, à toutes les questions.

Résultats: Si des programmes structurés de mieux-être étaient offerts à différents degrés dans les 17 universités, la plupart d'entre eux relevaient d'unités locales, de départements ou de divisions. Il y avait une grande diversité de postes de direction établis. Quant à la répartition du travail par postes, les façons de faire variaient énormément. Dans la pratique

From the *Division of Pediatric Emergency Medicine, Departments of Pediatrics \& Medicine, Schulich School of Medicine and Dentistry, London, $\mathrm{ON} ;{ }^{\dagger}$ Children's Health Research Institute, London Health Sciences Centre, London, ON; ${ }^{\ddagger}$ Department of Emergency Medicine, McGill University, Montreal, QC; ${ }^{\S}$ Department of Emergency Medicine, University of Toronto, Toronto, ON; ${ }^{\mathbb{D} D e p a r t m e n t}$ of Emergency Medicine, Queen's University, Kingston, ON; and "Division of Emergency Medicine, Department of Medicine, Schulich School of Medicine and Dentistry, London, ON.

Correspondence to: Dr. Rodrick Lim, Children's Health Research Institute, London Health Sciences Centre, London, Canada 800 Commissioners Road East, London, Ontario, N6A 2V5; Email: rod.lim@Ihsc.on.ca

(c) Canadian Association of Emergency Physicians 2020

CJEM 2020;22(6):857-863

CAEP | ACMU
DOI 10.1017/cem.2020.408
$2020 ; 22(6)$ 
quotidienne, l'offre était bonne en ce qui concerne la nourriture et les séances de verbalisation, mais il en allait autrement pour les services de garde d'enfants, les chambres et le processus de suivi du personnel après un événement grave. Dans la majorité des centres, le personnel pouvait profiter de congés sabbatiques. Des programmes d'équité entre les sexes avaient été mis sur pied dans environ $50 \%$ des départements et des séances de réflexion étaient tenues annuellement. Les responsables des centres ont aussi fait état de programmes de départs en congé ( $82 \%)$, d'accueil et d'intégration (64\%) ainsi que de réorientation (94\%). Quant aux prestations de maladie $(76 \%)$ et aux caisses de retraite $(76 \%)$, elles dépendaient du type d'engagement et des liens avec l'établissement universitaire. Enfin, une politique de transparence fiscale avait été établie dans $53 \%$ des programmes.

Conclusion: Le mieux-être et l'épuisement professionnel constituent des problèmes d'une importance cruciale en médecine d'urgence au Canada. L'enquête générale sur les programmes de mieux-être a permis de faire ressortir les bons points, mais aussi de mettre en lumière des éléments susceptibles d'amélioration à l'avenir. Chacun des centres pourra envisager différentes possibilités courantes lorsque viendra le temps d'élargir ou de mettre sur pied des programmes de mieux-être.

Keywords: Physician wellness, administration

\section{INTRODUCTION}

Fostering a culture of wellness in emergency medicine (EM) is a critical component to the delivery of highquality clinical care. Wellness is an important protective factor that reduces physician burnout. In EM, where rates of burnout rank among the highest of all medical specialties, this is sorely needed. ${ }^{1-3}$

Burnout is indiscriminate, impacting staff physicians, residents, medical students, patients, and hospitals. ${ }^{4-6}$ Specifically, burnout is associated with increased rates of depression, substance use, and suicidal ideation among physicians and residents. ${ }^{4,7-9}$ Doctors and residents with burnout have higher rates of error ${ }^{4,6-8,10}$ and lower patient satisfaction. ${ }^{6}$ Burnout and stress also impact the ability to perform challenging procedures. ${ }^{6}$ Finally, burnout increases physician turnover and absenteeism, lowers productivity, and increases desire to leave practice. ${ }^{6-8,11}$ At hospital and systems levels, these factors have important implications on the overall functioning of the workforce. A recent systematic review and meta-analysis indicates that both individual-focused and structural/organizational strategies can result in clinically meaningful reductions in burnout among physicians. $^{12}$

The Canadian Association of Emergency Physicians (CAEP) Wellness Committee was formed in 2018 to advocate and promote personal and professional wellbeing in EM across Canada. In keeping with the Section mission surrounding physician and resident wellness, an environmental scan survey was conducted to establish a greater understanding of wellness activities and policies in Canadian academic EM programs. Academic sites were chosen as the initial area of focus as a proxy for broader functioning and for the impact these programs have upon the wellness of future physicians. Highlighting local strengths and weaknesses, this environmental scan serves as a pulse check on the status of wellness activities in academic EM departments across Canada. In addition, this scan forms the foundation for planning future wellness initiatives to address gaps in wellness programming nationally.

\section{METHODS}

An 89-question questionnaire was developed with a focus on the following themes related to wellness in EM: formal wellness programs and leadership opportunities, shift scheduling, daily and long-term wellness measures, career transitions, and financial considerations (online Supplemental Appendix). The development and design of survey questions was based on consensus among wellness leads. The questionnaire used a combination of questions including yes/no and numerical responses as well as areas to provide free-text clarification. The questionnaire was reviewed and pilot tested among members of the CAEP Wellness Committee Executive, and revised for clarity. The final questionnaire was distributed by means of email to designated department/division heads and/or clinician wellness leads (or equivalent program directors) across 17 academic programs in Canada. Nonresponding programs were contacted by the lead author (R.L.) per ethics protocol to confirm correct contact information, and to discuss/confirm the most appropriate individual to provide information if open to participation. The lead author (R.L.) contacted each individual site as required to review data with each 
wellness lead (or equivalent) in a series of telephone discussions where discrepancies existed, to ensure all questions were clearly answered. A variable response could be recorded by the responder. In academic centers where the survey was distributed to multiple hospitals due to size of program, answers that were discrepant (i.e., three hospitals said yes, two said no) a variable response was selected for the overall academic center. Data were entered into a Microsoft Excel® 2011 (Microsoft Corp., Redmond, WA) spreadsheet for analysis. Descriptive statistics including proportions, means, medians, and ranges were calculated. Data collection was complete.

\section{RESULTS}

While formal wellness programs may exist in varying degrees across the 17 universities, most initiatives were found to exist only at local divisional or departmental levels. Only $37 \%$ of programs currently track physician wellness in any manner, primarily at the division level. Only $12 \%$ of all programs track wellness regularly and in a formal manner. There is a broad variability of established leadership positions that have been reserved for Physician wellness, existing across many levels (Table 1). Please note, academic programs were said to be variable in a selection if either some but not all hospitals within an academic center had a program, or within a hospital, some but not all consultants had a benefit based on their academic status.

Shift work in EM affects provider well-being as it disrupts circadian rhythms. ${ }^{13}$ Shift characteristics were found to vary tremendously across the 17 academic institutions. While most programs tried to account for circadian rhythms in shift scheduling, 7 of 17 (41\%) did not do so. Despite this, there were many initiatives that appeared to meet not only the individual needs of doctors, but tried various techniques, such as casino shifting, and varying shift lengths (Table 2).

In terms of specific factors and programming related to the promotion of daily wellness, areas that had the greatest consistency of availability were food (59\%), and any form of debriefing process after critical incidents (41\%) Access to childcare, sleep rooms, and formal policies to follow-up with staff following critical incidents was found to be the most limited (Table 3). In regard to long-term wellness initiatives, 10 of 17 (59\%) provide some form of sabbatical or extended vacation program,

\begin{tabular}{|c|c|c|c|}
\hline & Yes & No & Variable* \\
\hline \multicolumn{4}{|l|}{ Tracking of physician wellness: } \\
\hline Overall \% & 6 & 71 & 23 \\
\hline University \% & 6 & 94 & \\
\hline Hospital \% & 12 & 88 & \\
\hline Department/division \% & 24 & 76 & \\
\hline \multicolumn{4}{|l|}{ Position in charge of physician wellness } \\
\hline University \% & 47 & 53 & \\
\hline Hospital \% & 29 & 71 & \\
\hline Department/division \% & 41 & 59 & \\
\hline $\begin{array}{l}\text { If yes, department/division position have } \\
\text { protected time or stipend } \%\end{array}$ & 71 & 29 & \\
\hline \multicolumn{4}{|l|}{ Counselling availability: } \\
\hline University \% & 59 & 41 & \\
\hline Hospital \% & 47 & 47 & 6 \\
\hline \multicolumn{4}{|l|}{ Mentorship: } \\
\hline $\begin{array}{l}\text { Do you have a mentorship program \% } \\
\text { Miscellaneous: }\end{array}$ & 29 & 41 & 30 \\
\hline $\begin{array}{l}\text { Does your hospital of employment provide } \\
\text { any funding for physician wellness } \\
\text { initiatives } \%\end{array}$ & 0 & 71 & 29 \\
\hline
\end{tabular}

of which the majority are voluntary. Roughly $50 \%$ of departments reported having some form of gender equity program, and annual retreats (Table 4). Transitions are known to cause some the greatest periods of stress for physicians during their career.

In regard to easing transitions, many programs have developed programs for the initiation of leaves (82\%), or onboarding $(64 \%)$. There is a significant amount of

\begin{tabular}{|c|c|c|c|}
\hline & Yes & No & Variable \\
\hline \multicolumn{4}{|l|}{ Shifts: } \\
\hline Scheduled to follow circadian rhythm \% & 29 & 24 & 47 \\
\hline $\begin{array}{l}\text { Flexible enough to accommodate } \\
\text { individual needs } \%\end{array}$ & 59 & 12 & 29 \\
\hline \multirow[t]{2}{*}{ Second-call policy \% } & 65 & 35 & \\
\hline & Full & Casino & Variable \\
\hline \multirow{2}{*}{$\begin{array}{l}\text { What is the structure of your night } \\
\text { shifts } \%\end{array}$} & 59 & 29 & 12 \\
\hline & Mean & Min & Max \\
\hline \# per month is full-time & 13.25 & 10 & 16 \\
\hline How many hours is the typical night shift & 7.3 & 5 & 10 \\
\hline
\end{tabular}




\begin{tabular}{|c|c|c|c|}
\hline & Yes & No & Variable \\
\hline \multicolumn{4}{|l|}{ Exercise facility or discount: } \\
\hline By hospital of employment \% & 29 & 59 & 12 \\
\hline By department/division \% & 18 & 18 & 64 \\
\hline \multicolumn{4}{|l|}{ Food: } \\
\hline Free supplied by hospital of employment \% & 0 & 100 & \\
\hline By department/division \% & 12 & 82 & 6 \\
\hline $\begin{array}{l}\text { Available for staff in your hospital } 24 \text { hours a } \\
\text { day, } 7 \text { days a week, } 365 \text { days of the year } \%\end{array}$ & 59 & 41 & \\
\hline \multicolumn{4}{|l|}{ Childcare: } \\
\hline By hospital of employment \% & 6 & 82 & 12 \\
\hline By department/division \% & 0 & 100 & \\
\hline \multicolumn{4}{|l|}{ Miscellaneous: } \\
\hline $\begin{array}{l}\text { Provide a location for physicians to } \\
\text { breastfeed } \%\end{array}$ & 12 & 53 & 35 \\
\hline $\begin{array}{l}\text { Provide sleep rooms for staff after call/night } \\
\text { shifts } \%\end{array}$ & 18 & 53 & 29 \\
\hline $\begin{array}{l}\text { Debriefing policy/process, after critical } \\
\text { incidents } \%\end{array}$ & 41 & 24 & 35 \\
\hline $\begin{array}{l}\text { Policy/process to follow-up with physician } \\
\text { staff after critical incidents, to ensure their } \\
\text { psychological well-being } \%\end{array}$ & 12 & 65 & 23 \\
\hline
\end{tabular}

reorientation programming for clinicians returning from leave $(94 \%)$ but almost all cite variable development of these programs (Table 5).

\begin{tabular}{|c|c|c|c|}
\hline & Yes & No & Variable \\
\hline \multicolumn{4}{|l|}{ Sabbatical / extended vacation: } \\
\hline Sabbatical or extended vacation ( $>3$ weeks) $\%$ & 35 & 41 & 24 \\
\hline Is it voluntary $(\mathrm{N}=6) \%$ & 83 & 17 & \\
\hline Is it paid $(N=6) \%$ & 50 & 50 & \\
\hline \multicolumn{4}{|l|}{ Gender equity: } \\
\hline $\begin{array}{l}\text { Does your department/division have a } \\
\text { program to promote gender equity } \%\end{array}$ & 12 & 53 & 35 \\
\hline If yes, is it formal or informal ( $\mathbf{N}=2) \%$ & 100 & & \\
\hline $\begin{array}{l}\text { If yes, is it voluntary or mandatory } \\
(\mathbf{N}=2) \%\end{array}$ & 50 & 50 & \\
\hline \multicolumn{4}{|l|}{ Other events: } \\
\hline \multirow[t]{2}{*}{ Do you have an annual retreat $\%$} & 59 & 41 & \\
\hline & Mean & Min & Max \\
\hline $\begin{array}{l}\text { \# of department/division wellness rounds/ } \\
\text { seminars over the past year }\end{array}$ & 2 & 0 & 6 \\
\hline $\begin{array}{l}\text { \# of department/division social events for } \\
\text { physician staff in the past year }\end{array}$ & 3.5 & 1 & 8 \\
\hline
\end{tabular}

Table 5. Environmental survey responses regarding programs for easing transition $(\mathrm{N}=17)$

\begin{tabular}{|c|c|c|c|}
\hline & Yes & No & Variable \\
\hline \multicolumn{4}{|l|}{ Department/division have a: } \\
\hline $\begin{array}{l}\text { Onboarding or orientation program for new } \\
\text { consultants \% }\end{array}$ & 35 & 35 & 30 \\
\hline $\begin{array}{l}\text { Transition to practice program for new } \\
\text { consultants } \%\end{array}$ & 35 & 47 & 18 \\
\hline $\begin{array}{l}\text { Reorientation for consultants returning from } \\
\text { leave } \%\end{array}$ & 6 & 6 & 88 \\
\hline $\begin{array}{l}\text { Assistance to families/spouses in locating } \\
\text { housing/schools for new attending } \\
\text { hires } \%\end{array}$ & 6 & 53 & 41 \\
\hline \multicolumn{4}{|l|}{ Department/division policies for: } \\
\hline $\begin{array}{l}\text { Leaves for consultants (health, parental, } \\
\text { grieving etc.) } \%\end{array}$ & 41 & 18 & 41 \\
\hline $\begin{array}{l}\text { Consultants returning from prolonged } \\
\text { leave } \%\end{array}$ & 24 & 70 & 6 \\
\hline \multirow{2}{*}{$\begin{array}{l}\text { Consultants toward the end of their } \\
\text { careers? (e.g., no night shifts after } \\
\text { age 55) \% }\end{array}$} & 59 & 23 & 18 \\
\hline & Mean & Min & Max \\
\hline $\begin{array}{l}\text { What percentage of your staff have taken a } \\
\text { personal or medical leave (excluding } \\
\text { parental leave) in the past year? \% }\end{array}$ & 11.5 & 1 & 22 \\
\hline
\end{tabular}

In regard to financial programs, many divisions cite variable support of health benefits (76\%) and pensions (76\%), with several depending on type of appointment and relationship to the university. There are some programs (53\%) showing fiscal transparency (Table 6).

Table 6. Environmental survey responses regarding financial setup / benefits $(N=17)$

Yes No Variable

Health benefits provided by:

University \%

Hospital of employment \%

Department/division \%

$\begin{array}{rrr}12 & 47 & 41 \\ 6 & 94 & \\ 0 & 18 & 82 \\ 18 & 53 & 29 \\ 12 & 88 & \\ 0 & 18 & 82 \\ 24 & 47 & 29 \\ 6 & 70 & 24\end{array}$




\section{DISCUSSION}

This report is the first comprehensive review of wellness activities and programs within Canadian academic EM centers. Significant activity was found across all of the evaluated domains, including formal wellness programs and leadership opportunities, shift scheduling, daily and long-term wellness measures, career transitions, and financial considerations. The most striking finding was the variability and inconsistency of wellness program availability between and within centers. This likely reflects the nature of the rapidly evolving landscape of wellness in EM. The specific example of low numbers of breastfeeding spaces and policies for returns after leaves is particularly concerning. This report would suggest that a comprehensive survey within divisions/ departments may lead to some opportunities to declare a set of minimum standards for programs to decrease variability between sites or academic versus clinical appointment.

We note three tangible positive findings that were evident from the survey. First, counselling was available at the university or hospital level in a large percentage of academic sites. This is critically important given recent research showing a large bias against seeking help among doctors surveyed by the Canadian Medical Association. ${ }^{14}$ Furthermore, the College of Family Physicians and Royal College of Physicians and Surgeons of Canada's accreditation standards mandate that academic EM residency programs establish and maintain means for resident physicians to access counselling services for support with stress, burnout, or crisis. ${ }^{15-17}$ Despite this positive finding, there remains room for improvement as four academic centers did not have either hospital or university level support. Second, $77 \%$ of academic sites have some degree of departmental policies for physicians at the end of their careers. Given the large reliance on shift work, and the difficulties with adaptation to disruptions of circadian rhythm with aging, the progressive policies that most academic centers have adapted is encouraging. This is important as overall dissatisfaction has been shown to be a significant factor underlying intention to quit and early retirement. ${ }^{18-20}$ Likourezos et al. reported that emergency physicians who were dissatisfied with professional autonomy were more likely to seek a new position or exit the profession. ${ }^{20}$ Third, almost $60 \%$ of centers were found to hold an annual retreat. Although not much literature is available on the effect of retreats on wellness, they do provide a departmental/divisional forum for reflection and future goal setting, which is intrinsically tied to professional fulfillment and wellness.

The Institute for Healthcare Improvement introduced the Triple Aim in 2008 as a framework that describes an approach to optimizing health system performance through: (1) improving the patient experience of care (including quality and satisfaction); (2) improving the health of populations; and (3) reducing the per capita cost of health care. ${ }^{21}$ Currently, many institutes now pursue the "quadruple aim" in 2014 with institutions advocating for health care team wellness as a crucial fourth aim. ${ }^{22}$ Our survey suggests that, if this fourth aim is included in the framework, there is currently a significant gap in top-down support/structures. In fact, it is difficult to even measure the metric of wellness. In our survey, most wellness programs were at the division/ department level, not at the hospital or university level. It appears we have a long way to go before the quadruple aim can become a meaningful reality.

Our study had a $100 \%$ response rate, indicating a comprehensive assessment of Canadian academic EM programs has been achieved. The survey assessed a broad range of infrastructure consistent with career sustainability and wellness. As in prior academic scans in EM, the data obtained from this survey can be the springboard to encourage further initiatives.

There are several limitations to our study. Many wellness issues are managed at the hospital level, e.g., shifts. Due to the surveys being carried out at the medical schools and not the 60+ academic hospitals in Canada, we do not have a complete picture. The survey was based on the report of local physician champions, who are likely to be the most aware of programming and, thus, may not reflect the general awareness of all departmental/division members. In addition, wellness initiatives may stem from university, hospital, or departmental/divisional programs, and particularly so in programs with multiple sites (e.g., British Columbia). Although we delineated the source of programming, the responses best reflect the wellness champions' local situation, and it is possible that other hospitals or groups had differing initiatives that were not included here. Although we attempted to examine gender equity, this survey was not designed to examine diversity issues in general, which would be an opportunity for future research. Finally, we did not ask about the status of the local electronic medical record (EMR) system and supports for physicians in this regard. ${ }^{23}$ 
EM programs can use the results of this study as a framework to examine what systems are currently in place, determine their relative weaknesses and strengths, and set goals and priorities for development. National collaboration between EM programs to develop more comprehensive wellness programs may speed our specialty toward the Quadruple Aim goal. Our results may aid in discussions with hospitals, universities, and stakeholders to help gain support for these initiatives. The authors believe that the high priority areas for wellness initiatives are as follows: the development of a structured practice of critical incident debriefing; the provision of places to either sleep surrounding night shifts and/or spaces to breastfeed on shift; and the creation of programs to assist physicians with transitions, such as onboarding or returning to work following leave.

\section{CONCLUSION}

This research provides a comprehensive review of wellness programs at academic EM sites across Canada. We highlight important work across the domains of formal wellness programs and leadership opportunities, shift scheduling, daily and long-term wellness measures, career transitions, and financial considerations. Highlighting local strengths and weaknesses, individual centers can review where they stand in comparison to survey findings, and plan and advocate for future growth of wellness programs. This may also form the foundation for establishing future wellness initiatives to address gaps in wellness programming nationally.

Supplemental material: The supplemental material for this article can be found at https://doi.org/10.1017/cem.2020.408.

Acknowledgments: We particularly thank Shanna Scarrow from CAEP for logistical support. In addition, we are very grateful for the cooperation of emergency medicine leaders from each university: British Columbia (Jim Christenson), Alberta (Bill Sevcik), Calgary (Eddy Lang), Saskatchewan (James Stempian, Alison Turnquest), Manitoba (Alecs Chochinov), Northern Ontario (Gary Bota,), Western (Adam Dukelow), McMaster (M. Welsford), Toronto (Anil Chopra), Queens (David Messenger), Ottawa (Guy Hebert), McGill (Marc Afilalo, Sara Ahronheim), Montreal (Nathalie Cairefon), Laval (Xavier Huppe), Sherbrooke (Eric Lachance, Martin Basaillon), Dalhousie (David Petrie, Laurel Murphy), and Memorial (Michael Parsons).

Financial support: This research received no specific grant from any funding agency, commercial or not-for-profit sectors. The authors have no financial relationships relevant to this article to disclose.
Competing interests: The authors have no conflicts of interest relevant to this article to disclose.

\section{REFERENCES}

1. Canadian Medical Association. CMA workforce survey 2017. 2017. Available at: http://cma.andornot.com/en/surveydata/default.aspx (accessed January 18, 2020).

2. Shanafelt T, Boone S, Tan L, et al. Burnout and satisfaction with work-life balance among US physicians relative to the general US population. Arch Intern Med 2012;172:1377-1385.

3. Shanafelt TD, West CP, Sinsky C, et al. Changes in burnout and satisfaction with work-life integration in physicians and the general US working population between 2011 and 2017. Mayo Clin Proc 2019;94(9):1681-1694.

4. Taher A, Crawford S, Koczerginski J, Argintaru N. Position statement on resident wellness. CFEM 2018;20(5):671-684. doi: $10.1017 / \mathrm{cem} .2018$.

5. Reith TP. Burnout in United States healthcare professionals: a narrative review. Cureus 2018:10(12):e3681. doi: 10.7759/ cureus.3681.

6. American Psychiatric Association. APA Wellbeing Ambassador Toolkit: Physician Burnout and Depression: Challenges and Opportunities. January 2018. Available at: https://www. psychiatry.org/psychiatrists/practice/well-being-and-burnout/well-being-resources (accessed November 15, 2019).

7. Wallace JE, Lemaire JB, Ghali WA. Physician wellness: a missing quality indicator. Lancet 2009;374(9702):1714-1721.

8. Patel RS, Sekhri S, Bhimanadham NN, Imran S, Hossain S. A review on strategies to manage physician burnout. Cureus 2019;11(6):e4805. doi: 10.7759/cureus.4805.

9. Atkinson P, Ducharme J, Campbell S. (2017). CJEM debate series: \#Burnout - Burnout is inevitable in clinical emergency medicine practice. CFEM 2017;19(5):386-389. doi: 10.1017/ cem.2017.395.

10. Patel RS, Bachu R, Adikey A, Malik M, Shah M. Factors related to physician burnout and its consequences: a review. Behav Sci (Basel) 2018;8(11):98. doi: 10.3390/bs8110098.

11. Lee FJ, Stewart M, Brown JB. Stress, burnout, and strategies for reducing them. What's the situation among Canadian family physicians? Can Fam Physician 2008;54:234-235.e1-5

12. West CP, Dyrbye LN, Erwin PJ, Shanafelt TD. Interventions to prevent and reduce physician burnout: a systematic review and meta-analysis. Lancet 2016;388(10057):22722281. doi: 10.1016/S0140-6736(16)31279-X

13. Frank J, Ovens H. Shiftwork and emergency medical practice. CFEM 2002;4(6):421-428. doi: 10.1017/S1481803500007934.

14. Simon C, McFadden T, Canadian Medical Association (CMA). National Physician Health Survey: The Process, Preliminary Data, and Future Directions 2017. Canadian Conference on Physician Health; 2017 Sep 7-9; Ottawa. Ottawa: CMA; 2017.

15. Taher A, Hart A, Dattani N, et al. Emergency medicine resident wellness: Lessons learned from a national survey. CFEM 2018;20(5):721-724. doi: 10.1017/cem.2018.416.

16. Royal College of Physicians and Surgeons of Canada. Accreditation of Residency Programs. Specific Standards of Accreditation for Residency Programs in Emergency Medicine; 2008. 
Available at: http://www.royalcollege.ca/rc/faces/oracle/ webcenter/portalapp/pages/viewDocument.jspx?document_id= TZTEST3RCPSCED000759\&_afrLoop=212816199436362 66\&_afrWindowMode=0\&_afrWindowId=w4vpqg9s6_1-!\% 40\%40\%3F_afrWindowId\%3Dw4vpqg9s6_1\%26document_ id\%3DTZTEST3RCPSCED000759\%26_afrLoop\%3D212 81619943636266\%26_afrWindowMode\%3D0\%26_adf.ctrlstate\%3Dw4vpqg9s6_17 (accessed May 9, 2020)

17. The College of Family Physicians of Canada. Standards of Accreditation for Residency Programs in Family Medicine; 2018. Available at: https://portal.cfpc.ca/ResourcesDocs/ uploadedFiles/_Shared_Elements/Documents/ 20180701_RB_V1.2_ENG.pdf (accessed May 9, 2020).

18. Cydulka RK, Korte R. Career satisfaction in emergency medicine: the ABEM longitudinal study of emergency physicians. Ann Emerg Med 2008;51(6):714-722.
19. Landon BE, Reschovsky JD, Pham HH, Blumenthal D. Leaving medicine: the consequences of physician dissatisfaction. Med Care 2006;44:234-242.

20. Likourezos A, Chalfin DB, Murphy DG, Sommer B, Darcy $\mathrm{K}$, Davidson SJ. Physician and nurse satisfaction with an electronic medical record system. F Emerg Med 2004;27:419-424.

21. Berwick DM, Nolan TW, Whittington J. The triple aim: care, health, and cost. Health Aff (Millwood) 2008;27(3):759769.

22. Bodenheimer T, Sinsky C. From triple to quadruple aim: care of the patient requires care of the provider. Ann Fam Med 2014;12(6):573-576. doi: 10.1370/afm.1713.

23. Melnick ER, Dyrbye LN, Sinsky CA, et al. The association between perceived electronic health record usability and professional burnout among US physicians. Mayo Clin Proc 2020;95(3):476-487. doi: 10.1016/j.mayocp.2019.09.024 